\title{
EFFECTIVENESS OF VERMICOMPOSTING IN MANAGEMENT OF ORGANIC WASTES USING EISENIA FOETIDA AND PERIONYX FAVATUS IN CENTRAL ZOO JAWALAKHEL, NEPAL
}

\author{
M. Dhimal', I. Gautam ${ }^{2}$ and R. Tuladhar ${ }^{3}$
}

\section{ABSTRACT}

Management of Zoo wastes has been increasing problem in urban areas. The major part of the Zoo waste is organic material contributing from animal dungs, garbage and litter which can be converted into fertile compost. We used the vermicomposting techniques for converting the elephant dung, rhino dung, garbage and litter into compost in relatively short time compared to traditional method of composting. The physico-chemical and microbiological parameters of thus prepared compost were tested adopting standard scientific methods. The analysis showed that $\mathrm{pH}$, organic matter content, moisture content, nitrogen, phosphorous, potassium and (Carbon:Nitrogen) C: $\mathrm{N}$ value are appropriate for utilizing in the farming. Thus vermicomposting is one of the viable options for converting huge amount of organic waste into high quality compost effectively.

Key words: elephant dung, rhino dung, garbage, litter, waste management

\section{INTRODUCTION}

Inadequate safe disposal of solid wastes resulting in garbage and sanitation situation in a chaotic state poses a risk to public health in Nepal. There are several methods for the management of solid waste and composting for the management of biodegradable waste. Composting is a biological conversion of solid organic waste into usable end products such as fertilizers, substrates for mushroom production and biogas. Moreover, their high organic matter content and biological activity make composts effective in a variety of applications, including erosion control, re-vegetation, bio-filtration and bio-remediation (Alexander 1999). Another bio-technique for converting the solid organic waste faster into compost is vermicomposting. Vermicomposting differs from conventional composting in several ways (Gandhi et al. 1997). It is a simple and low cost, an environment friendly biotechnology system for the processing or treatment of organic wastes (Hand et al. 1988), in which certain species of earthworms are used to accelerate the breakdown of organic matter and stabilization of soil aggregates (Dindal 1985 ) to enhance the process of conversion of waste to a useful byproduct. Since it contains water-soluble nutrients, vermicompost is an excellent, nutrient-rich organic fertilizer and soil conditioner (Ravichandran et al. 2001).

The Central Zoo located at Jawalakhel in the Kathmandu Valley, houses a wide variety of mammals, birds and reptiles. These animals, numbering over 900 of 123 different species including 31 species of mammals, 63 of birds, 9 of reptiles and 20 of fishes. The waste generated 
from the Central Zoo is mainly organic in nature. The herbivorous animals such as Asian elephants, rhinos, hippos etc. produce large quantity of organic waste. The excreta produced by Asian elephant, One-horn rhinoceros followed by litter and garbage can be the major raw material for vermicomposting. An elephant produces an average of $106 \mathrm{~kg}$ dung daily which is semi-digested and a one-horn rhino produce about $56 \mathrm{~kg}$ of waste daily which constitute the major component of Zoo waste. In addition to this, there are huge quantities of organic waste and fodder from enclosures, vegetable, kitchen waste and fallen leaves.

The elephant waste is often either burned or made to naturally decompose for converting into manure which takes more than six months. Such type of practices are creating different environment problems as well as threatening the biodiversity. Agricultural waste, horticultural waste, animal waste, silkworm litter, plant biomass (leaf litter), weeds, kitchen waste after removing non-degradable waste material such as glass, plastic, strong rubber and metal can be vermicomposted (Kale 1995). Wong and Griffiths (1991) studied vermicomposting in the management of pig-waste in Hongkong, and found that Pheritima asiatica can stabilize most of the solids arising from the treatment of pig waste, including raw pig manure, suggesting that vermicomposting has a high potential as a unit process in the management of pig waste in Hongkong. Some reports, in Nepal, about potential for vermicomposting (Pradhan and Tamrakar 1999), microflora analysis of vermicompost, vermicast and gut of red earthworms (Yami et al. 2003), foot rot disease control using fermented products of compost and vermicompost (Manandhar and Yami, 2008), utilization of organic solid wastes using Eisenia foetida (Tamrakar 2005, Pant and Yami 2008) are available including interplay of microbial (Baral et al. 2012) in the literature. Nevertheless, literature regarding the effectiveness of vermicomposting in managing the dung of elephant and rhino which constitute the major component of the zoo waste is scarce. Therefore, to overcome with the environment problems, we worked in converting organic waste into vermicompost in 2004. The waste from the central zoo was quantified and categorized. The vermicompost was prepared from elephant dung, one-rhino dung, litter and garbage separately using two species of worms Eisenia foetida and Perionyx favatus. Our study was aimed to prepare vermicompost from animal dung and other organic wastes to improve sanitation in the Zoo premises, apart from generating considerable revenue in order to achieve self-sustenance and to determine whether the vermicomposting can effectively manage the major component of Zoo wastes and can produce high quality compost or not.

\section{MATERIALS AND METHODS}

In order to carry out the study, the consent was taken from the Central Zoo authority. The daily solid waste generation from different sections of the Zoo, composition of solid wastes and wastes generation per animals were surveyed. After quantifying the wastes generation and composition, the major categories of organic wastes consisting of elephant dung, rhino dung, garbage and litter were composted using vermicomposting technique within the premises of Central Zoo. The physico-chemical and microbiological parameters of thus prepared compost were analyzed to test the quality of compost using the standard scientific methods.

\section{Waste collection}

There were four sections and one nursery in Central Zoo. Each section had different types 
of animals and waste may vary with respect to composition and amount. The waste of each section was weighed sorting the waste in six broad categories: animal waste, litter and garbage, plastic, metals/glass, meat and paper. The wastes were enumerated twice per week. As the waste generation reached its peak on Saturday and Sunday and declined on Monday, care was taken to avoid the bias. For those animals whose waste (excreta) was not collected daily, their daily waste was estimated on the basis of total waste generation of that animal in a week. The zookeepers were pre-informed to collect the waste separately in previous days. The waste was weighed separately using portable weighing machine to know the composition and average generation of total waste within the Zoo premises.

\section{Vermicomposting}

The shed behind the elephant captivity of the Central Zoo was chosen for the vermicomposting. The waste for composting was collected by zookeepers. The materials required for the vermicomposting such as plastic sheet and jute bags were provided by Zoo.

\section{Preparation of bed}

Since it was a small scale project the composting was carried out inside the shed without using any container. The plastic bags were placed at the base to avoid the worms passing on the ground. Thereafter good bedding was made placing a layer of straw, litter and grass clipping above the plastic bags layer. A thin layer of compost was also placed at the bottom. Moisture on the bedding was maintained to provide resting-place and help earthworms to suck the surplus amount of moisture. Three beds consisting each of $50 \mathrm{~kg}$ elephant dung, one- horned Rhino dung and litter and garbage were prepared. A little amount of Effective Microorganism (EM) and Bokashi was also added after placing the waste on the bed. A separate bed was prepared for the conversion of rhino waste into the compost using EM.

\section{Inoculation of suitable species of the worms}

In this study Eisenia foetida and Perionyx favatus were used for composting obtained from Pesticide Monitor Network Nepal, Tahachal. Approximately 1000 worms of each species were inoculated in one week old prepared bed with waste. To maintain the moisture content, water was sprinkled at weekly interval. The pile was covered with a jute bag soaked with water to maintain moisture and to avoid direct light and flies.

\section{Measurement of physico-chemical parameters}

Moisture content was calculated as weight loss after the moist sample is dried at $105^{\circ} \mathrm{C}$ for 24 hours in hot air oven. A digital pH meter was calibrated with the help of standard Buffer solution of $\mathrm{pH} 4.2$ and 9, and used to determine the $\mathrm{pH}$ of the compost. The organic matter content of the soil, dung and vermicompost samples were determined as described by Walkely and Black method (1934).

Nitorgen, Potassium and Phosphorous (NPK) analysis of compost samples was carried out in Soil Science Division, Nepal Agriculture Research Council, Khumultar. The total nitrogen content of compost was determined by using Kjeldahl method (1883) in which organic nitrogen compounds were converted into ammonium sulphate by digestion with concentrated sulphuric acid. The total phosphorous $\left(\mathrm{P}_{2} \mathrm{O}_{5} \%\right)$ content in the fused aliquot (sample) was prepared with 
chlorostanous reduced molybdophosphoric blue colour method. The blue colour was measured by colorimeter. The Potassium $\left(\mathrm{K}_{2} \mathrm{O} \%\right)$ content in the fused aliquot was diluted and directly measured by Flame-photometer.

Carbon:Nitrogen $(\mathrm{C}: \mathrm{N})$ ratio was calculated from the values of Organic matter and Nitrogen Percent

$\mathrm{C}: \mathrm{N}$ ratio = Organic matter $\%$

$1.8 \times$ Nitrogen \%

(FRSRD 1980)

\section{Microbiological analysis of compost}

The serial dilution method and Spread Plate method were used to study the number and colony characters of bacteria in the samples as described by Sharma and Ghimire (1996). Microscopic examination of bacteria by gram staining Huckers method (1921) was carried out following the procedure described by Bailey and Scott (Baron and Finegold 1990). The microscopic morphological features of the filamentous fungi provided the reliable criterion for the identification. For the microscopic morphology, the slides were prepared by using Cellophane Tape Method (Thirumurthy et al. 2002).

\section{RESULTS AND DISCUSSION}

\section{Daily waste generation}

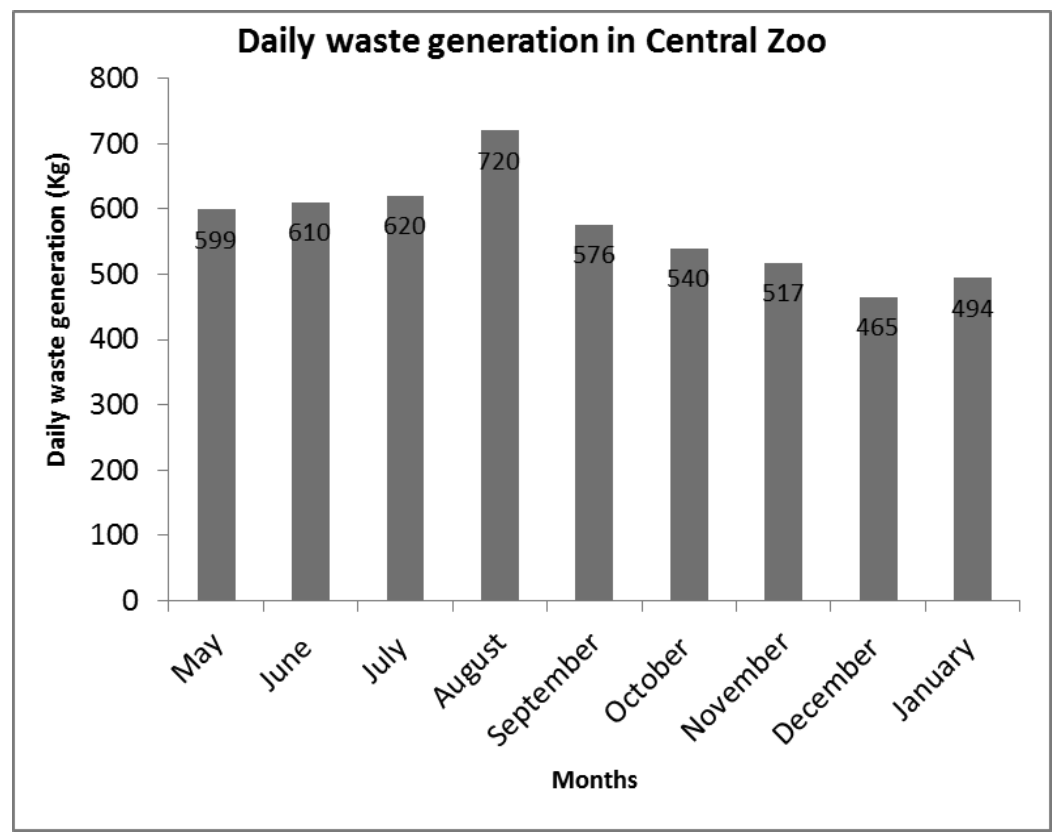

Figure1. Daily waste generation in Central Zoo. 
The amount of waste generated was found to vary with the month of the year. As shown in figure 1, the waste generation was highest in August $(720 \mathrm{~kg} /$ day $)$ and lowest in December ( $465 \mathrm{~kg} /$ day). The mean waste generation was $571.55 \pm 45.37 \mathrm{~kg}\left(8 \mathrm{~d} . \mathrm{f}, \mathrm{t}_{0.05}\right)$. The generation of the waste was the function of the animal number and the weather condition. In the days of high wind and high rainfall, the amount of the litter and garbage was more. The amount of waste generation was also found to be influenced by the day of sampling. Because the number of visitors was high on Saturday and Sunday, the waste generation was also high. Since Zoo closes on Monday for visitors least amount of waste is generated on this day.

\section{Composition of waste}

\section{Composition of waste in Central Zoo (\%)}

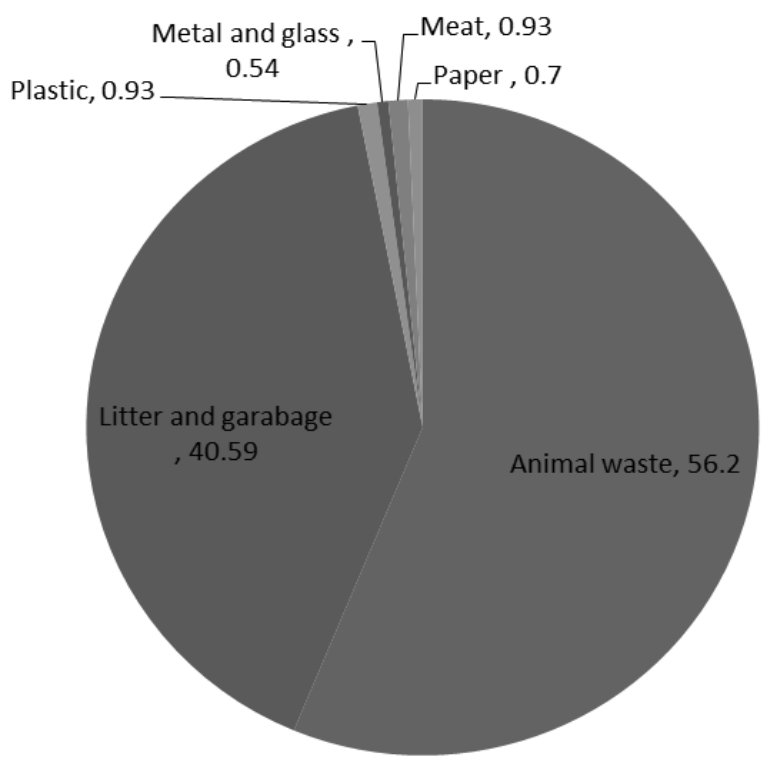

Animal waste

Litter and garabage

Plastic

Metal and glass

Meat

Paper

Figure 2. Composition of waste in Central Zoo.

The waste composition was divided into six groups; animal wastes, litter and garbage, plastics, metal/glass, meat and paper. In present study, animal waste was found $56.20 \%$ followed by litter and garbage (40.59\%), plastics $(0.93 \%)$, and paper $(0.9 \%)$ (fig. 2$)$. This data assured that about $97 \%$ wastes can be converted into compost. The solid waste generated in $\mathrm{kg}$ by individual herbivore animal was also estimated. The anatomy of an elephant's stomach is simple and digests only $50 \%$ of the food consumed (WWF 2003). Staple diet includes Kuchhi (grass rolls) that consists of molasses, salt and rice painstakingly wrapped in the banana stalks or rice stalks. The elephant is also fed with green grass and fodder. Therefore, the highest amount of 
waste generation per animal was found in elephant (106 kg per individual). The elephant dung was found fibrous and light odoured during the study. The second highest amount of waste generation I was found in one-horned rhino ( $76 \mathrm{~kg} / \mathrm{day})$. The rhinoceros waste was found to be less fibrous than elephant and high in water content. The excreta of the blue bull, elephant and rhino were in the form of dung but the dung of spotted deer, black buck and barking deer were observed in the form of pellets.

\section{Amount of waste and time required for composting}

Table1. Weight and time for preparation of compost from different sources.

\begin{tabular}{|l|l|l|l|l|l|}
\hline SN & $\begin{array}{l}\text { Raw materials for } \\
\text { composting }\end{array}$ & $\begin{array}{l}\text { Weight of raw } \\
\text { materials (kg) }\end{array}$ & $\begin{array}{l}\text { Weight of } \\
\text { compost (kg) }\end{array}$ & Ratio & $\begin{array}{l}\text { Time taken for the } \\
\text { maturation of } \\
\text { compost in days }\end{array}$ \\
\hline 1. & Elephant dung & 50 & 22 & $2.27: 1$ & 42 \\
\hline 2. & Rhino dung & 50 & 26 & $1.92: 1$ & 56 \\
\hline 3. & Litter and garbage & 50 & 12 & $4.16: 1$ & 75 \\
\hline 4. & Rhino dung with EM & 50 & 24 & $2.08: 1$ & 70 \\
\hline
\end{tabular}

Time required for the maturation of the compost and weight of compost produced from different sources is given in the table 1. During this study, it was found that the food best accepted by the earthworm was elephant dung because it was lighter, easy to maintain aerobic condition, partially decomposed and frequent spraying of water help to maintain moisture balance. However, the number of worms was not found increased compared to rhino dung vermicomposting. In equal number of worms and equal amount of foods, the elephant dung was converted into mature compost within 42 days. In contrast, rhino dung took 56 days, and litter and garbage in 75 days. Without using the worms but in presence of EM, the rhino dung was found to be converted into mature compost in 70 days. Our finding on maturation time of elephant and rhino dung vermicomposting was similar to Rodale (1975), who stated two months or less for conversion period. As stated by Bhattarai (2003), maturation of vermicompost using Eisenia foetida took 75 to 90 days when mixing farm waste of plant origin with animal dung. Contrary to this, our study showed that the time elapsed for the maturation of vermicompost using Eisenia foetida for all three types of compost was shorter. The compost produced from elephant dung, rhino dung and litter and garbage is found in the ratio $2.27: 1,1.92: 1$ and $4.16: 1$ respectively. The amount of compost produced from the rhino dung was highest, while the amount of compost produced from litter and garbage was found to be the lowest. 
Physico-chemical parameters of dungs and composts

Table 2. pH analysis of vermicomposts.

\begin{tabular}{|c|c|c|c|c|c|}
\hline \multirow{2}{*}{ Sources } & \multirow{2}{*}{$\begin{array}{l}\text { Sample } \\
\text { size } \\
\text { (n) }\end{array}$} & \multirow{2}{*}{$\begin{array}{l}\text { Mean } \\
\text { pH value }\end{array}$} & \multirow{2}{*}{$\begin{array}{l}\text { Std. } \\
\text { deviation } \\
\text { (SD) }\end{array}$} & \multicolumn{2}{|c|}{$\begin{array}{l}95 \% \text { confidence interval } \\
\text { for mean }\end{array}$} \\
\hline & & & & Lower bound & $\begin{array}{l}\text { Upper } \\
\text { bound }\end{array}$ \\
\hline Elephant dung & 4 & 8.375 & 0.0500 & 8.2954 & 8.4546 \\
\hline Rhino dung & 4 & 8.5 & 0.0816 & 8.3701 & 8.6299 \\
\hline Elephant vermicompost & 4 & 8.225 & 0.0957 & 8.0727 & 8.3773 \\
\hline Rhino vermicompost & 4 & 7.075 & 0.0500 & 6.9954 & 7.1546 \\
\hline $\begin{array}{l}\text { Rhino dung compost with } \\
\text { EM }\end{array}$ & 4 & 7.475 & 0.0957 & 7.3227 & 7.6273 \\
\hline Litter \& garbage compost & 4 & 7.925 & 0.0957 & 7.7727 & 8.0773 \\
\hline
\end{tabular}

As shown in table 2, it was found that, to some extent, the earthworms have the capability of changing the compost condition, and thus ease their own life. The experiment by Albanell et al. (1988) with sheep manure using earthworm showed the change of $\mathrm{pH}$ value from 9.1 to 7.2 in 12 weeks. In the present study also, the pH value of all three types of vermicompost and rhino compost with EM was slightly decreased from alkaline condition to towards neutral. The moisture content influences activities, metabolism, population and growth of the worms. Common earthworms live in soils containing $12 \%$ to $34 \%$ moisture (Edward and Lofty 1972). 
Table 3. Moisture content of vermicomposts.

\begin{tabular}{|c|c|c|c|c|c|}
\hline \multirow{2}{*}{ Sources } & \multirow{2}{*}{$\begin{array}{c}\text { Sample } \\
\text { size } \\
\text { (n) }\end{array}$} & \multirow{2}{*}{$\begin{array}{c}\text { Mean } \\
\text { moisture } \\
\text { content } \\
(\%)\end{array}$} & \multirow{2}{*}{$\begin{array}{l}\text { Std. } \\
\text { deviation } \\
\text { (SD) }\end{array}$} & \multicolumn{2}{|c|}{$\begin{array}{l}\text { 95\% confidence interval for } \\
\text { mean }\end{array}$} \\
\hline & & & & Lower bound & Upper bound \\
\hline Elephant dung & 4 & 36.55 & 0.9146 & 35.0945 & 38.0055 \\
\hline Rhino dung & 4 & 39.01 & 0.5753 & 38.0944 & 39.9256 \\
\hline Elephant vermicompost & 4 & 24.9325 & 0.5243 & 24.0982 & 25.7668 \\
\hline Rhino vermicompost & 4 & 30.6625 & 0.2321 & 30.2931 & 31.0319 \\
\hline Rhino with EM compost & 4 & 29.6075 & 0.7699 & 28.3823 & 30.8327 \\
\hline Litter \& garbage compost & 4 & 30 & 0.8165 & 28.7008 & 31.2992 \\
\hline
\end{tabular}

Lunt and Jacobson (1944) recorded moisture content to be $31.4 \%$ in the casts and $27.4 \%$ in the topsoil. As shown in table 3, the results elicited that moisture content was ranged from 24.93 to $30 \%$ in different vermicomposts and $29.60 \%$ in rhino compost with EM. The moisture content decreased in final vermicast in comparison to the original dung of elephant and rhino. Microorganisms need moisture to assimilate nutrients. The higher the moisture content the greater the chance for growth of microorganisms. But excessive moisture above $60 \%$ can lower the internal temperature, which inhibits the oxygen flow creating the anoxic condition. 


\section{Organic matter analysis}

Table 4. Organic matter measurement.

\begin{tabular}{|c|c|c|c|c|c|}
\hline \multirow{2}{*}{ Sources } & \multirow{2}{*}{$\begin{array}{c}\text { Sample } \\
\text { size } \\
\text { (n) }\end{array}$} & \multirow{2}{*}{$\begin{array}{c}\text { Mean } \\
\text { organic } \\
\text { matter } \\
(\%)\end{array}$} & \multirow{2}{*}{$\begin{array}{l}\text { Std. } \\
\text { deviation } \\
\text { (SD) }\end{array}$} & \multicolumn{2}{|c|}{$\begin{array}{l}95 \% \text { confidence interval for } \\
\text { mean }\end{array}$} \\
\hline & & & & Lower bound & Upper bound \\
\hline Elephant dung & 4 & 31.37 & 0.9501 & 29.8581 & 32.8819 \\
\hline Rhino dung & 4 & 41.295 & 0.4900 & 40.5153 & 42.0747 \\
\hline Elephant vermicompost & 4 & 26.9425 & 4.8388 & 19.2428 & 34.6422 \\
\hline Rhino vermicompost & 4 & 26.915 & 0.9295 & 25.4359 & 28.3941 \\
\hline Rhino with EM compost & 4 & 30.955 & 0.6204 & 29.9678 & 31.9422 \\
\hline Litter \& garbage compost & 4 & 8.295 & 0.73944 & 7.1184 & 9.4716 \\
\hline
\end{tabular}

As tabulated in table 4, the organic matter content of vermicomposts decreased compared to the initial dung. This is supported by the result of the experiments carried out by Albanell et al. (1988) in which the organic matter was found to be decreased. The mean organic matter content in elephant vermicompost, rhino vermicompost and rhinocompost with EM was decreased by $14.12 \%, 34.82 \%$ and $25.04 \%$ respectively compared to organic matter in respective initial dung. The organic matter content of litter and garbage vermicompost was found very low compared to the value given by (Maharjan 2004, Pandey 2004, Tamrakar 2005). 
Total nitrogen (\%) analysis

Table 5. Total nitrogen (\%) analysis.

\begin{tabular}{|l|l|l|l|l|l|}
\hline & \multirow{2}{*}{ Sources } & $\begin{array}{c}\text { Sample } \\
\text { size } \\
\text { (n) }\end{array}$ & $\begin{array}{c}\text { Mean total } \\
\text { Nitrogen \% }\end{array}$ & $\begin{array}{c}\text { Std. } \\
\text { de- } \\
\text { viation } \\
\text { (SD) }\end{array}$ & \multicolumn{2}{|c|}{$\begin{array}{r}\text { 95\% confidence interval for } \\
\text { mean }\end{array}$} & Lower bound & Upper bound \\
\hline Elephant dung & 4 & 1.2425 & 0.0050 & 1.2345 & 1.2505 \\
\hline Rhino dung & 4 & 1.63 & 0.0082 & 1.617 & 1.643 \\
\hline Elephant vermicompost & 4 & 1.2825 & 0.0126 & 1.2625 & 1.3025 \\
\hline Rhino vermicompost & 4 & 1.43 & 0.0081 & 1.417 & 1.443 \\
\hline Rhino with EM compost & 4 & 1.6175 & 0.0050 & 1.6095 & 1.6255 \\
\hline Litter \& garbage compost & 4 & 0.83 & 0.0316 & 0.7797 & 0.8803 \\
\hline
\end{tabular}

The nitrogen content in the elephant vermicompost was increased by $3.22 \%$ than in the elephant dung. The nitrogen content in the rhino vermicomposting and rhino compost with EM was decreased by $12.26 \%$ and $1.22 \%$ respectively compared to the nitrogen content of rhino dung (table 5). The decrease in nitrogen content in rhino compost may be due to the rapid decomposition of nitrogenous organic material and volatilization of the end product. As compared to the result of Tamrakar (2005) in the vermicomposting of the waste from Kathmandu valley using Eisenia foetida, the nitrogen content of various vermicompost was found to be higher except in the vermicompost of litter and garbage. The low content of nitrogen in the vermicompost of litter and garbage may be due to the richness of nitrogenous wastes and poor in carbon content, which result in the loss of nitrogen.

\section{Analysis of available phosphorous}

The analysis of available phoshorous $\left(\mathrm{P}_{2} \mathrm{O}_{5}\right) \%$ in the dungs and compost revealed that, percentage of phosphorous increased in the vermicompost of the elephant but decreased in the vermicompost of rhino dung (table 6). The phosphorous content in the elephant vermicompost increased by $28.50 \%$ than in the elephant dung. The phosphorous content in the rhino vermicompost decreased by $37.76 \%$ compared to the phosphorous content of rhino dung but the phosphorous content of the rhino vermicompost with EM found to be increased by $5.31 \%$ compared to rhino dung. 
Table 6. Analysis of available phosphorous (\%).

\begin{tabular}{|c|c|c|c|c|c|}
\hline \multirow{2}{*}{ Sources } & \multirow{2}{*}{$\begin{array}{l}\text { Sample } \\
\text { size } \\
\text { (n) }\end{array}$} & \multirow{2}{*}{$\begin{array}{c}\text { Mean } \\
\text { available } \\
\text { Phosphorous } \\
(\%)\end{array}$} & \multirow{2}{*}{$\begin{array}{l}\text { Std. devia- } \\
\text { tion (SD) }\end{array}$} & \multicolumn{2}{|c|}{$\begin{array}{l}\text { 95\% confidence interval for } \\
\text { mean }\end{array}$} \\
\hline & & & & Lower bound & Upper bound \\
\hline Elephant dung & 4 & 2.2125 & 0.0100 & 2.2045 & 2.2205 \\
\hline Rhino dung & 4 & 1.8875 & 0.1723 & 1.8795 & 1.8955 \\
\hline $\begin{array}{l}\text { Elephant vermi- } \\
\text { compost }\end{array}$ & 4 & 2.8475 & 0.0129 & 2.8323 & 2.8627 \\
\hline $\begin{array}{l}\text { Rhino vermicom- } \\
\text { post }\end{array}$ & 4 & 1.17 & 0.0263 & 1.0295 & 1.3105 \\
\hline $\begin{array}{l}\text { Rhino with EM } \\
\text { compost }\end{array}$ & 4 & 1.98 & 0.0822 & 1.9575 & 2.0025 \\
\hline $\begin{array}{l}\text { Litter \& garbage } \\
\text { compost }\end{array}$ & 4 & 1.1225 & 0.0289 & 1.0624 & 1.1826 \\
\hline
\end{tabular}

As compared to study by Tamrakar (2005) the phosphorous content of various vermicomposts was found to be higher including rhino compost with EM.

Table 7. Analysis of potassium (\%).

\begin{tabular}{|c|c|c|c|c|c|}
\hline \multirow{2}{*}{ Sources } & \multirow{2}{*}{$\begin{array}{l}\text { Sample } \\
\text { size } \\
\text { (n) }\end{array}$} & \multirow{2}{*}{$\begin{array}{l}\text { Mean } \\
\text { potassium } \\
(\%)\end{array}$} & \multirow{2}{*}{$\begin{array}{l}\text { Std. } \\
\text { deviation } \\
\text { (SD) }\end{array}$} & \multicolumn{2}{|c|}{$\begin{array}{l}95 \% \text { confidence interval for } \\
\text { mean }\end{array}$} \\
\hline & & & & Lower bound & $\begin{array}{l}\text { Upper } \\
\text { bound }\end{array}$ \\
\hline Elephant dung & 4 & 2.705 & 0.0100 & 2.6891 & 2.7209 \\
\hline Rhino dung & 4 & 3.8075 & 0.1723 & 3.5333 & 4.0817 \\
\hline $\begin{array}{l}\text { Elephant vermicom- } \\
\text { post }\end{array}$ & 4 & 3.7425 & 0.0129 & 3.7225 & 3.7625 \\
\hline $\begin{array}{l}\text { Rhino vermicom- } \\
\text { post }\end{array}$ & 4 & 2.0975 & 0.0263 & 2.0557 & 2.1393 \\
\hline $\begin{array}{l}\text { Rhino with EM } \\
\text { compost }\end{array}$ & 4 & 4.075 & 0.0827 & 3.9441 & 4.2059 \\
\hline $\begin{array}{l}\text { Litter \& garbage } \\
\text { compost }\end{array}$ & 4 & 4.26 & 0.0289 & 4.215 & 4.305 \\
\hline
\end{tabular}


The potassium content of elephant dung was increased by $38.51 \%$, while in the vermicompost of rhino dung it was decreased by $45 \%$. The potassium content in the rhino compost with EM increased by $7.10 \%$. The potassium content of litter and garbage vermicompost was found highest $(4.26 \%$ ) (table 7$)$. The potassium content of all composts was found higher than the result revealed by Tamrakar (2005).

\section{The C:N ratio analysis}

The C:N ratio of the organic matter added to the soil is of primary importance to the source of mineralization. Generally the material with a C:N ratio of 20:1 or lower can directly provide mineral nitrogen (Satchell et al.1971). Earthworms gradually lower the C:N ratio as they break down material during their metabolism. This lowering the $\mathrm{C}: \mathrm{N}$ ratio is achieved mainly by release of carbon during respiration (Edwards et al. 1985). In this study C:N ratio was found to be lowered from 14.70:1 to $10.85: 1$ in the vermicompost of elephant dung and from 14.9:1 to $10.95: 1$ in the vermicompost of rhino dung. The C:N ratio was decreased from 14.9:1 to 11.30:1 in the rhino compost with EM.

\section{Microbiological analysis}

Table 8. Total bacterial count from different types of compost.

\begin{tabular}{|l|l|l|}
\hline SN & Compost from different sources & Total bacterial count (CFU/gm) \\
\hline 1. & Elephant vermicompost & $7.32 \times 10^{5}$ \\
\hline 2. & Rhino vermicompost & $6.96 \times 10^{6}$ \\
\hline 3. & Litter and garbage compost & $4.05 \times 10^{4}$ \\
\hline 4. & Rhino compost using EM & $8.15 \times 10^{3}$ \\
\hline
\end{tabular}

The total bacterial count was measured by counting the colonies observed in the culture plate of different dilutions and expressed in terms of colony forming units (cfu) (table 8) The total bacterial count from compost of different sources varies from $8.15 \times 10^{3}$ in the rhino compost using EM and highest $6.96 \times 10^{6}$ in the vermicompost of rhino.

Table 9. Total fungal count from compost of different sources.

\begin{tabular}{|l|l|l|}
\hline SN & Compost of different sources & Total fungal count (cfu/gm) \\
\hline 1. & Elephant vermicompost & $4.32 \times 10^{3}$ \\
\hline 2. & Rhino vermicompost & $3.96 \times 10^{4}$ \\
\hline 3. & Compost from litter and garbage & $1.25 \times 10^{3}$ \\
\hline 4. & Rhino compost using EM & $1.15 \times 10^{3}$ \\
\hline
\end{tabular}

Similarly, the total fungal count was found varied from $1.15 \times 10^{3}$ in rhino compost using EM and highest in the rhino dung vermicompost which was $3.96 \times 10^{4}$. This result clearly revealed 
that vermicompost was superior in microbial count compared to other composts.

The present study contributes to the microbiological understanding of commercial composts, whose fungal component is often overlooked despite the favorable and unfavorable effects of fungi in the situations in which composts are employed.

The Central Zoo which is located in Jawalakhel, Lalitpur, Nepal accommodates many wild faunas which produces large amount of wastes daily. Most of the waste is organic which can be converted into valuable compost. Among the organic waste, most are produced by elephant, One-horned Rhinoceros and litter and garbage. We used vermicomposting technique for managing the waste of elephant, One-horned Rhino and litter and garbage and conclude that vermicomposting is one of the effective method to convert those wastes generated by giant animals into high quality compost effectively in relatively short period of time. This technique can be practicised in large scale in Elephant rearing centers of the country such as in Hattisars (Elephant Centres) of Nepal located in different parts of the country.

\section{ACKNOWLEDGEMENTS}

The first author acknowledges National Trust for Nature Conservation (NTNC) for providing partial funding for this study. The authors acknowledge the Central Department of Environmental Science, Tribhuvan Univeristy and Soil Science Division, Nepal Agricultural Research Council, Khumular. Lalitpur for providing the laboratory facility to analyse the samples.

\section{REFERENCES}

Albanell, E., J. Plaixats and T. Cabrero, 1988. Chemical changes during vermicomposting (Eisenia foetida) of sheep manure mixed with cotton industrial wastes. Biol. Fertil. Soil., 6(3): 266-269.

Alexander,R.,1999. Compost markets grow with environmental applications. Biocycle, March: 43-44.

Baral, B.,N. Bhattarai and G. Shrestha, 2012. Microbial effectiveness through vermicomposting technique for the biological stabilization of solid waste. Journal of Natural History Museum, 26:26-135.

Baron, E.J. and S.M. Finegold,1990. Bailey and Scott's Diagnostic Microbiology. St. Louis, Mo, CV Mosby Co. (8th edition).

Bhattarai, S., 2003. Quality compost production with vermicomposting from the farm and household waste. In Proceedings of International Conference on Women, Science and Technology for Poverty Alleviation, Kathmandu, March 31-April 2, pp 85-90.

Dindal, D.L.,1985. Soil animals and soil fabric production: Facts and perceptions. Quaestiones Entomologicae, 21:587-594.

Edwards, C.A. and J.R. Lofty,1972. Biology of Earthworms. Chapman and Hall, London.

Edwards, C.A., I. Burrows, K.E. Fletcher and B.A. Jones,1985. The use of earthworms for composting farm wastes. In Gasser, J.K.R. (ed) Composting Agricultural and Other Wastes. Elsevier, London and New York, pp 229-241. 
FRSRD,1980. Standard Methods of Analysis for Soil, Plant tissues, Water and Fertilizer. Farm Resources and Systems Research Division (FRSRD), Los Banos, Laguna:Phillippine Council for Agricuture and Resources Research, 194 p.

Gandhi, M., V. Sangwan, K.K. Kapoor and N. Dilbaghi,1997. Composting of household wastes with and without earthworms. Environment and Ecology,15(2):432-434.

Hand, P.,W.A.Hayes,J.C. Frankland and J.E. Satchell,1988. The vermicomposting of cow slurry. Pedobiologia, 31:199-209.

Hucker, G. J.,1921. A new modification and application of the Gram stain. J. Bacteriol., 6:396-397.

Kale, R.D.,1995. Vermicomposting has a bright scope. Indian Silk, 34:6-9.

Kjeldahl, J. Z.,1883. A new method for the determination of nitrogen in organic bodies. Analytical Chemistry, 22:366.

Lunt, H.A. and H.C.M. Jacobson,1944. The chemical composition of earthworm casts. Soil Sci.,58:367-375.

Maharjan, K., 2004. Management of solid waste of Kalimati fruits and vegetable wholesale market (KFVWM) through different methods of composting. M.Sc. Dissertation, Central Department of Environment Science, Tribhuvan University, Kirtipur, Kathamandu, Nepal.

Manandhar,T. and K.D. Yami, 2008. Biological control of Foot Rot Disease using fermented products of compost and vermicompost. Scientific world, 7(7):52-57.

Pandey,S., 2004. Management of dmestic oganic wste by dfferent methods of composing, M.Sc. Dissertation, Central Department of Environment Science, Tribhuvan University, Kirtipur, Kathamandu, Nepal.

Pant, S.R. and K.D. Yami, 2008. Selective utilization of organic solid wastes by Earthworm (Eisenia foetida). Nepal Journal of Science and Technology, 9:99-104.

Pradhan, M. and A.S. Tamrakar,1999. A study on the potential for vermicomposting of organic waste and its implementation. In Proceedings of third National Conference on Science and Technology, RONAST, 2:1333.

Ravichandran,C.,G.E. Chandrasekaran and C.F. Priyadharsini, 2001.Indian J. Environ. Prot., 21:538-542.

Rodale,J.I.,1975. The Complete Book of Composting. In Rodale, J.I. (ed), Rodale Books, Inc.

Satchell,J.E.,D.K. Undley and J.K. Hibberd,1971. Computation of confidence limits for estimates of net primary production. In Rosswall, T. (ed) Systems analysis in northern coniferous forests-IBP workshop. Ecological bulletin no.14, Stockholm:Swedish Natural Science Research Council. pp 75-82.

Sharma, A.P. and P. Ghimire,1996. A Handbook of Practical Microbiology. Sagar Publication Kathmandu, Nepal.

Tamrakar, A.S., 2005. Utilization of biowastes through vermicomposting. Nepal Journal of 
Science and Technology, 6:69-71.

Thirumurthy, M.,G. Sethuraman and C.R. Srinivas, 2002. KOH mount for superficial fungal infections using cellophane tape: comparison with standard technique. Indian Journal of Dermatology, Venereology and Leprology,68(3):136.

Walkley, A. and I.A. Black,1934. An examination of the Degtjareff method for determining organic carbon in soils: effect of variations in digestion conditions and of inorganic soil constituents. Soil Sci.,63:251-263.

Wong, S.H. and D.A. Griffiths, 1991. Vermicomposting in the management of pig waste in Hong Kong. World Journal of Microbiology and Biotechnology,7(6):593-595.

WWF Nepal, 2003. Managing domesticated elephants in Nepal (Brochure). Kathmandu: WWF Nepal Program.

Yami, K. D., S. Bhattarai and S. Adhikari, 2003. Vermicomposting and microflora analysis of vermicompost, vermicast and gut of red earthworms. Nepal Journal of Science and Technology, 5:121-126.

\section{AUTHOR'S ADDRESS \\ Meghnath Dhimal'}

Nepal Health Research Council, Ramshahpath, Kathmandu, Nepal (email:meghdhimal @gmail.com)

\section{Ishan Gautam²}

Natural History Museum, Tribhuvan University, Swayambhu, Kathmandu, Nepal Reshma Tuladhar ${ }^{3}$

Central Department of Microbiology, Tribhuvan University, Kirtipur, Kathmandu, Nepal 